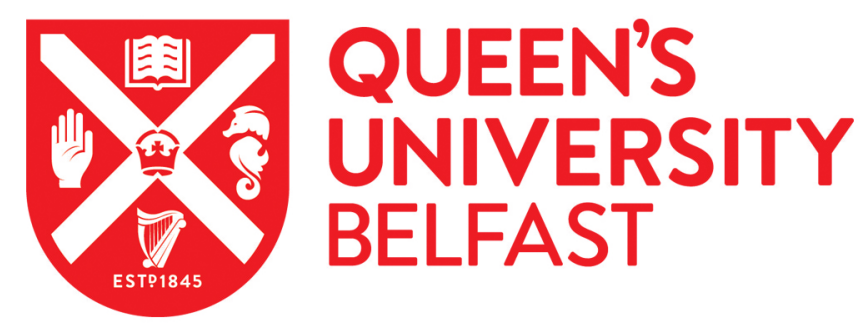

\title{
The Developing Habitus of the Anti-Social Behaviour Practitioner: From Expansion in Years of Plenty to Surviving the Age of Austerity
}

Brown, K. J. (2013). The Developing Habitus of the Anti-Social Behaviour Practitioner: From Expansion in Years of Plenty to Surviving the Age of Austerity. Journal of Law and Society, 40(3), 375-402.

https://doi.org/10.1111/j.1467-6478.2013.00631.x

Published in:

Journal of Law and Society

Document Version:

Peer reviewed version

Queen's University Belfast - Research Portal:

Link to publication record in Queen's University Belfast Research Portal

Publisher rights

Copyright 2013 Wiley. This work is made available online in accordance with the publisher's policies. Please refer to any applicable terms of use of the publisher.

\section{General rights}

Copyright for the publications made accessible via the Queen's University Belfast Research Portal is retained by the author(s) and / or other copyright owners and it is a condition of accessing these publications that users recognise and abide by the legal requirements associated with these rights.

Take down policy

The Research Portal is Queen's institutional repository that provides access to Queen's research output. Every effort has been made to ensure that content in the Research Portal does not infringe any person's rights, or applicable UK laws. If you discover content in the Research Portal that you believe breaches copyright or violates any law, please contact openaccess@qub.ac.uk. 


\title{
The Developing Habitus of the Anti-Social Behaviour Practitioner: From Expansion in Years of Plenty to Surviving the Age of Austerity
}

\author{
KeVIn J. BRown \\ Queen's University Belfast, k.brown@qub.ac.uk
}

Specialist anti-social behaviour units are common within social housing providers, with many established in response to the policies of the New Labour governments of 1997-2010. These units now find themselves operating in a different political and financial environment. Following the English riots of 2011, the Coalition government, whilst imposing budgetary cuts across the public sector, called on social housing providers to intensify their role in tackling disorder. This article explores the habitus or working cultures within anti-social behaviour units post-New Labour. It does so through empirical research conducted in the aftermath of the English riots. The research finds that practitioners view their work as a core function of social housing provision. They have developed an understanding of human behaviour, which crosses the criminal and social policy fields with a wide skillset to match. A number of factors including national policy, community expectations, and multi-partnership engagement influence their dynamic working culture.

\section{INTRODUCTION}

Following the English riots of summer 2011, the perceived problem of antisocial behaviour (ASB) and disorder once again came to dominate the

+The author would like to thank Newcastle University for funding the 2011 research project. Thanks also to those who participated in the research and those practitioners who provided feedback at a subsequent day conference. Final thanks to Richard Collier, Colin Murray, Kathryn Hollingsworth, Jane Donoghue, Chris Chipchase, and the anonymous reviewers for comments on earlier drafts of this article. Any errors remain my own. 
political and media discourse. ${ }^{1}$ In the United Kingdom, ASB represents an umbrella term for low-level criminality, nuisance, and public disorder. ${ }^{2}$ How to tackle such behaviour has been the subject of continued debate and political attention in the country for almost two decades. ${ }^{3}$ A combination of national and local policy innovation, overseen first by the New Labour governments (1997-2010) and now the Coalition has produced an expanding toolkit of interventions to deal with the perceived problem. ${ }^{4}$ Combining social and criminal policy approaches, these interventions - epitomized by the anti-social behaviour order (ASBO) - have been the subject of much academic critique. ${ }^{5}$ Through this period of hyper-innovation in ASB management, ${ }^{6}$ a cadre of practitioners has developed who implement, interpret, and transform national policy at a local level. They 'are the human subjects through whom and by whom ... [the ASB agenda] has been brought about.. ${ }^{7}$ Within this broad family of practitioners, there exist specialist ASB units based within social housing providers. They make for an interesting case study of working culture within the ASB industry as they are dedicated solely to the task of tackling ASB, they have some of the broadest powers to do so and they have been the subject of sustained central government attempts to influence their working practices. This article explores through empirical research, including an analysis of policy documents and semi-structured interviews, the working cultures found within social housing ASB units in 2011, after thirteen years of New Labour and following the first full year of the Coalition government.

The approach taken in this article is influenced by the work of Hughes and Gilling who have explored the habitus of a related occupation, the community safety manager. ${ }^{8}$ As with their research, this article approaches

1 A. Stratton and A. Sparrow, 'Cameron and Miliband go head to head over riots' Guardian, 15 August 2011 at <http://www.guardian.co.uk/uk/2011/aug/15/ cameron-miliband-head-head-riots $>$.

2 A. Millie, Anti-Social Behaviour (2009).

3 S. Hodgkinson and N. Tilley, 'Tackling Anti-Social Behaviour: Lessons from New Labour to the Coalition Government' (2011) 11 Criminology and Criminal Justice 283; Home Office, Putting victims first - more effective responses to antisocial behaviour (2012; Cm. 8367).

4 Hodgkinson and Tilley, id.

5 E. Burney, Making People Behave: Antisocial Behaviour Politics and Policy (2009); E. Burney and L. Gelsthorpe, 'Do We Need a "Naughty Step"? Rethinking the Parenting Order after Ten Years' (2008) 47 Howard J. of Criminal Justice 470;

A. Crawford, 'Dispersal Powers and the Symbolic Role of Anti-Social Behaviour Legislation’ (2008) 71 Modern Law Rev. 753.

6 Crawford, id.

7 D. Garland, The Culture of Control: Crime and Social Order in Contemporary Society (2001) 24.

8 G. Hughes and D. Gilling, "Mission Impossible"? The Habitus of the Community Safety Manager and the New Expertise in the Local Partnership Governance of Crime and Safety' (2004) 4 Criminology and Criminal Justice 129; G. Hughes, The Politics of Crime and Community (2007). 
occupational culture from the perspective of Bourdieu's relational theory, ${ }^{9}$ 'which explains cultural practice as the result of interaction between cultural dispositions (habitus) and structural positions (field), [situating] culture in the social and political context. ${ }^{10}$ In identifying the habitus of the ASB practitioner, this article is examining the working philosophy - the internalized rationalities, the taken-for-granted assumptions, and the established routines - that guide practitioners in their day-to-day work. Bourdieu's concept of habitus recognizes that working cultures are neither static nor uniform. ${ }^{11}$ The article situates the habitus of units within the changing fields in which practitioners operate, with particular attention paid to shifts in the national policy agenda, changes in community expectations, and developments in multi-agency working. ${ }^{12}$

\section{BACKGROUND}

Following the emergence of community safety officers in the 1990s, the 2000s witnessed 'the rise of the ASB officer as a potentially new career path in the local governance of "problematic behaviour". 13 A survey published in 2002 found that 50 per cent of respondent local authorities had a dedicated team of officers whilst 28 per cent of registered social landlords did so (the total number of agencies contacted was 78). ${ }^{14}$ More recent data (2011/12) from 148 predominately-larger social housing providers reported that 60 per cent have specialist officers engaged in tackling ASB ${ }^{15}$ The cost of managing ASB across the social housing sector in Britain in 2011 was estimated to be nearly $£ 300$ million with $£ 145$ million on staffing costs alone. ${ }^{16}$ The management of ASB within areas of social housing has thus grown into a significant industry.

In the United Kingdom, social housing providers have a long established role in behavioural management. ${ }^{17}$ Their most recent high-profile involve-

9 P. Bourdieu, Outline of a Theory of Practice (1977).

10 J. Chan, 'Changing Police Culture' (1996) 36 Brit. J. of Criminology 109, at 112.

11 id.; Hughes and Gilling, op. cit., n. 8.

12 Hughes and Gilling, id.

13 Hughes, op. cit., n. 8, p. 103.

14 J. Nixon and C. Hunter, Initiatives by Social Landlords to Tackle Anti-social Behaviour (2003).

15 HouseMark, ASB Benchmarking: Analysis of Results 2011/12 (2012). This result was consistent with their two previous annual surveys which reported figures of 58 per cent in 2010/11 and 60 per cent in 2009/10. They acknowledge that smaller social housing providers who are less likely to participate in the survey may be less likely to have dedicated ASB staff. HouseMark, ASB Benchmarking: Analysis of Results 2010/ 11 (2011); HouseMark, ASB Benchmarking: Analysis of Results 2009/10 (2010).

16 id.

17 E. Burney, Crime and Banishment: Nuisance and Exclusion in Social Housing (1999); J. Donoghue, Anti-Social Behaviour Orders: A Culture of Control (2010); J. 
ment in crime reduction began in the 1980s, led predominately by urban Labour-controlled councils that were suffering stubbornly high crime rates. ${ }^{18}$ The concept of 'community safety' and some of the key principles and practices underlying it, such as multi-agency working, were brought to national attention in the recommendations of a report commissioned and published by the Home Office in 1991. ${ }^{19}$ Through the Social Landlords Crime and Nuisance Group (and its predecessor, the Local Authority Working Group on ASB) these forerunner agencies promoted innovation and reform in the tackling of disorder and nuisance behaviour serving as an inspiration for a Labour Party keen to demonstrate it was tough on crime. ${ }^{20}$

Although the focus on partnership working was initially on local authorities and the police, central government has required providers of social housing, whether local authorities, arm's length management organizations $(\mathrm{ALMOs})^{21}$ or registered social landlords ${ }^{22}$ to play an increasingly prominent role. ${ }^{23}$ Under the New Labour governments of 1997-2010, Parliament provided local agencies including social landlords with a powerful toolkit to manage ASB in their localities with an expectation of use. ${ }^{24}$

The New Labour governments were not content simply to encourage local agencies to accept responsibility for the tackling of ASB; instead, they sought through a number of steering mechanisms to influence local responses to the problem. One of the more visible methods for doing so was the promotion of national policy agendas/campaigns on ASB. The first of these was the Together Campaign launched in 2003, which promoted the new ASB enforcement toolkit (which included the ASBO) and sought through various initiatives to educate and train practitioners to use it. ${ }^{25}$ In 2006, the New Labour government launched a second campaign, the Respect Agenda, which called for practitioners to adopt a twin-track approach

Flint, 'Maintaining an Arm's Length? Housing, Community Governance and the Management of "Problematic" Populations' (2006) 21 Housing Studies 171.

18 A. Crawford, The Local Governance of Crime: Appeals to Community and Partnerships (1999); D. Gilling, Crime Reduction and Community Safety: Labour and the Politics of Local Crime Control (2007).

19 Home Office Standing Conference on Crime Prevention, Safer Communities: the Local Delivery of Crime Prevention through the Partnership Approach (the Morgan Report) (1991).

20 Burney, op. cit., n. 5.

21 A company established and owned by a local authority, whose function is to manage the social housing stock on the authority's behalf.

22 These are predominately housing associations but some are co-operatives, trusts or companies.

23 Registered Social Landlords were formerly included in these partnerships through the Crime and Disorder Strategies (Prescribed Descriptions) (England) Order 2004/ 118. Their membership status was upgraded under the Crime and Disorder Strategies (Prescribed Descriptions) (England) (Amendment) Order 2007.

24 Department of Communities and Local Government, Tackling anti-social behaviour: Tools and powers - toolkit for social landlords (2010).

25 Home Office, Together Tackling Antisocial Behaviour (2003). 
combining criminal and social policy responses to tackle the problem. ${ }^{26}$ Practitioners were encouraged to combine their enforcement powers with supportive interventions. ${ }^{27}$ This campaign was accompanied by the Respect Taskforce, which was headed by Louise Casey who became a high-profile champion of the agenda. ${ }^{28}$ Further steering mechanisms employed by the New Labour governments included a statutory obligation to draft and publish policies and procedures on $\mathrm{ASB},{ }^{29}$ the temporary funding of specialist posts and initiatives, ${ }^{30}$ auditing of adherence to standards of what government considered good practice in the field, ${ }^{31}$ and requirements to participate in regular national surveys on the use of ASB interventions. ${ }^{32}$

The efforts of successive New Labour governments from 1997 to 2010 contributed to the emergence of what Alison Brown categorized as an emerging profession or discipline. ${ }^{33}$ She argued, rather than founding work on the application of professional expertise, its practitioners relied on populist interventions promoted by national government and their own common-sense morality as to what works. ${ }^{34}$ This resulted in a blurring of occupational boundaries without sufficient consideration given to the repercussions, which, Brown argued, included increased social control and criminalization of those facing social exclusion. ${ }^{35}$ In contrast to Brown, empirical research by Hughes and Gilling on community safety managers found that despite pressures from central government, "many ... appear to manifest a habitus which accords more closely with the "old" liberal social democratic mentality than the neo-liberal turn of mind. ${ }^{36}$ Subsequent studies have found variation in the extent to which local agencies embraced the New Labour governments' initiatives, with evidence of a variety of responses ranging from enthusiastic engagement to apathy and resistance, with many in the middle choosing selective adaptation. ${ }^{37}$ In part, the variation in findings is due to

26 Home Office, The Respect Action Plan (2006).

27 id.

28 D. Walker, 'Hard Cases, Hard Casey: Home Office Action Plan's Tough Line on Antisocial Behaviour' Guardian, 8 October 2003, 4.

29 Anti-Social Behaviour Act 2003, s. 12.

30 Home Office, Respect and Responsibility - Taking a Stand Against Anti-Social Behaviour (2003).

31 Audit Commission, The Community Safety Key Lines of Enquiry and Descriptors for a Cross-Cutting Inspection (2006); Audit Commission, Landlord Services: Tenancy and Management Key Lines of Enquiry (2007).

32 Home Office, CDRP Surveys, at: <http://webarchive.nationalarchives.gov.uk/ 20100405140506/asb.homeoffice.gov.uk/members/article.aspx?id=12680>.

33 A.P. Brown, 'Anti-Social Behaviour, Crime Control and Social Control' (2004) 43 Howard J. of Criminal Justice 203.

34 id.

35 id.

36 Hughes and Gilling, op. cit., n. 8, p. 144.

37 A. Crawford, S. Lewis, and P. Taynor, Anti-social behaviour interventions with young people (2012); Donoghue, op. cit., n. 17; R. Matthews and D. Briggs, 'Lost in Translation: Interpreting and Implementing anti-social behaviour policies' in $A S B O$ 
studies focusing on different types of practitioners and partnership arrangements at different points in time. The focus of this article is on specialist ASB units within social housing providers post-New Labour. Time and locality impact on working practices; hence, this article focuses on units from different localities and their changing role in recent years.

The political field in which practitioners operate has significantly altered recently. Unlike the centralist approach of the previous New Labour administrations, the Coalition, elected in 2010, embraces a policy of localism, which advocates less central government intrusion at a local level. ${ }^{38}$ In February 2011, the Home Secretary, Theresa May, stated that whilst the government expected that ASB should remain a priority for local agencies, they were keen to promote:

A new approach to a problem which is fundamentally local, and which will be different in every area. The answers have to come not from the centre, but from professionals working on the ground and from communities themselves the people who know the victims and know the perpetrators. ${ }^{39}$

The Coalition government has either curtailed or not deployed some of the steering mechanisms of the previous administration. Importantly, auditing and surveying requirements for agencies hosting ASB units have been curtailed. $^{40}$ This does not mean that the Coalition has ignored the subject of ASB. In a response to the English riots of 2011, David Cameron called for an increased focus on tackling disorder with a 'security fightback ... matched by a social fightback', 41 a reworking of Tony Blair's 'tough on crime, tough on the causes of crime ${ }^{42}$ mantra. Cameron's 'Big Society' discourse, also influenced by communitarianism, bears similarities to the Respect Agenda of New Labour. ${ }^{43}$ Indeed the government recently appointed New Labour's Respect Tsar, Louise Casey, to head the newly established Troubled Families Team. ${ }^{44}$ In May 2013, the Coalition introduced a Bill to Parliament which seeks to reform the interventions available to tackle ASB, including increased powers for social housing providers. ${ }^{45}$ The Coalition has sought to

Nation: The Criminalisation of Nuisance, ed. P. Squires (2008) 87; P. Squires and D.E. Stephen, Rougher Justice: Anti-social behaviour and young people (2005).

38 For the statutory embodiment of this, see the Localism Act 2011.

39 Home Office, More Effective Responses to Anti-Social Behaviour (2011) 1.

40 Tenant Services Authority, A revised regulatory framework for social housing in England from April 2012 (2011).

41 D. Cameron, 'We are all in this together' at: $<$ http://www.conservatives.com/News/ Speeches/2011/08/David_Cameron_We_are_all_in_this_together.aspx $>$.

42 Labour Party, New Labour, Because Britain Dé-̄éves Better (1997).

43 Hodgkinson and Tilley, op. cit., n. 3.

44 P. Wintour, 'David Cameron appoints Louise Casey to lead government response to riots' Guardian, 12 October 2011, at <http://www.guardian.co.uk/society/2011/oct/ $12 /$ david-cameron-louise-casey-riots $>$.

45 ASB, Crime and Policing Bill 2013-14. K.J. Brown, 'Replacing the ASBO with the Injunction to Prevent Nuisance and Annoyance: A Plea for Legislative Scrutiny and Amendment' (2013) 8 Criminal Law Rev. 623. 
enact these policies within the context of significant financial cuts to the public sector. ${ }^{46}$ Many agencies across the criminal and social policy fields including social housing providers have been forced to reduce spending and personnel, curtailing the level and range of services they provide. ${ }^{47}$ The article examines how ASB units, which were largely a creation of New Labour, are adapting to life under the Coalition.

\section{METHODOLOGY}

A broad range of agencies is involved in the management of ASB. This includes social housing providers, local government, the police, youth offending teams, mediators, victim support organizations, probation, and third-sector providers of diversionary and preventative activities. Many of these agencies work in partnership through multi-agency panels and community safety groups. This article focuses on the work of specialist ASB units in social housing providers. The terms 'ASB unit' and 'ASB practitioner' are used within this context. Whilst the article examines the multi-agency partnership working of ASB units, it is a study of teams that are based within one agency.

This article discusses qualitative data involving in-depth semi-structured interviews and an analysis of policy documents. The data, which is the focus of this article, was gathered in late 2011, following the English riots. It involved the participation of ten units and 45 practitioners. This is supplemented by data from an earlier study conducted in 2007 involving 30 interviewees across eleven units. ${ }^{48}$ All of the 2011 units and six of the 2007 units were either based within ALMOs (7) or registered social landlords (10). Four of the 2007 units were based in local authorities. ${ }^{49}$ Seven of the 2011 units are in the North of England with a further two within London and one

46 HM Treasury, Spending Review (2010; Cm. 7942); J. Houghton, 'The partnership approach - an assessment of the present and future' (2012) 11 Safer Communities 105.

47 Family and Parenting Institute, Families on the Frontline? Local spending on children's services in austerity (2012); D. Faulkner, 'Criminal Justice reform at a Time of Austerity: What Needs to Be Done' in Lessons for the Coalition: An End of Term Report on New Labour and Criminal Justice, ed. A. Silvestri (2011) 79; J. Yates, 'What Prospects Youth Justice? Children in Trouble in the Age of Austerity' (2012) 46 Social Policy and Administration 432.

48 This data was gathered for the author's doctoral thesis. Different units participated across the two periods. The reason that the 2007 units were not revisited in 2011 is that the studies were treated as separate. However, on analysis of the 2011 data, the changing habitus of ASB units emerged as a strong research theme. This encouraged the revisiting of the 2007 data and the contrasting of the two data sets.

49 Of the local authority teams, three did not have responsibility for social housing provision and so caution has been used in contrasting their habitus with that of the 2011 units. 
in Northern Ireland. All of the 2007 units are in the North of England. Across the two studies, ten units are based within cities and eleven in towns.

There is no national register of ASB units and not all social landlords have such teams, so finding and selecting units for participation is heavily dependent on the use of online search engines and speculative invitation emails. Seven units in the 2007 sample agreed to participate following a call made through the email list of the Social Landlords Crime and Nuisance Group. Budgetary constraints meant that there was a focus on units based in the North of England. Sampling was undertaken to ensure that the units were dispersed across a range of localities including different towns and cities and police force areas.

The ten units that took part in the 2011 interviews ranged in size from five to 20 members with an average size of ten (Table 3 provides a breakdown of the personnel in the three larger teams). Each unit contained at least one manager (with more in some of the larger teams). The managers have responsibility for the operation of the units including the design and implementation of policy. Seventeen managers were interviewed in 2011 and 13 in 2007. Generic case officers investigate complaints and take actions to resolve them: 34 case officers participated in the research (15 in 2007 and 19 in 2011). Role-specialist officers were common within the larger 2011 units. ${ }^{50}$ Some of these officers divided their time between generic ASB caseofficer functions and specialist work, whilst others worked solely within their specialism. Eight interviews were conducted with officers with varied specialisms including mediation; preventative measures; the use of noise monitoring equipment; domestic violence; hate crime; and victim support. ASB units sometimes second personnel from other agencies and departments and interviews were conducted with two police officers and one mental health worker. Seconded personnel were always a small minority within the units.

Many of the practitioners had prior to joining their ASB unit been in other roles in their organization or elsewhere. Previous occupational experience is likely to shape the habitus of practitioners particularly in a new and developing occupation. ${ }^{51}$ In all but five of the interviews, there was discussion of occupational background. Results are shown in Table 1.

Each unit was asked to provide data on the extent of use of the different interventions in the two years before the interviews. Whilst units were able to provide data on the use of legal interventions (for example, the number of ASBOs or evictions obtained) there were problems in the supply of data on common non-court based interventions. This was due to a failure of the organizations to collate such data, a common problem in the ASB industry. ${ }^{52}$ National-level data from social housing providers is published annually by

50 Table 3 provides a breakdown of the personnel roles within the three largest units.

51 Hughes and Gilling, op. cit., n. 8.

52 A criticism made recently in Crawford et al., op. cit., n. 37. 
Table 1. The occupational backgrounds of the interviewees

\begin{tabular}{|c|c|c|c|}
\hline $\begin{array}{l}\text { Occupational } \\
\text { Background }\end{array}$ & $\begin{array}{l}2011 \\
\text { Interviewees }\end{array}$ & $\begin{array}{l}2007 \\
\text { Interviewees }\end{array}$ & Total \\
\hline Housing & 28 & 16 & 44 \\
\hline $\begin{array}{l}\text { Criminal Justice } \\
\text { (including seconded } \\
\text { police officers) }\end{array}$ & 1 & $\begin{array}{l}6 \text { (2 seconded } \\
\text { officers) }\end{array}$ & 7 \\
\hline $\begin{array}{l}\text { Welfare or social care } \\
\text { professions (including } \\
\text { seconded staff) }\end{array}$ & $\begin{array}{l}2 \text { (1 seconded } \\
\text { mental health } \\
\text { worker) }\end{array}$ & 0 & 2 \\
\hline Other & 6 & 4 & 10 \\
\hline No previous occupation & 3 & 4 & 7 \\
\hline Unknown & 5 & 0 & 5 \\
\hline TOTAL & 45 & 30 & 75 \\
\hline
\end{tabular}

HouseMark (a performance benchmarking service) and this is referred to in the article to supplement the interview and policy data.

This article focuses upon the commonalities in the habitus across the 2011 units, highlighting differences where space allows. It does not suggest that there was an identical approach to tackling ASB in each unit. Future publications will focus on the analysis of the 2011 data and will explore some of the more subtle differences between the units in greater depth.

In the quotations from interviews in the following sections, the job title of each interviewee, and whether from 2007 or 2011 cohort, are noted in order to inform the reader without risking the identification of the individual. Protecting identity in some instances has involved substituting a generic job title for the specific job title of the individual.

\section{SURVIVING BY BEING INDISPENSABLE}

The 2011 interviews were conducted after a prolonged period of successful expansion for the ASB industry. ${ }^{53}$ Seven of the ten units from 2011 provided comparative data on their change in size from 2006, with all but one showing an increase in the number of personnel; the remaining unit witnessed a small decrease. However, units were now operating in a period of uncertainty following the 2010 spending review. ${ }^{54}$ Practitioners, particularly managers, were aware that they were likely to face constraints on their budgets and possible reductions in personnel. There was, however, a consensus that their

53 Nixon and Hunter, op. cit., n. 14; HouseMark, op. cit., n. 15.

54 HM Treasury, op. cit., n. 46. 
units would survive. This self-assurance is perhaps surprising, given that they are relative newcomers to the ranks of public sector workers. One might have speculated that at times of contraction in the public sector it would be the less established departments within an organization that would face the greatest threat. When asked why they thought they would survive the cuts, a typical response was that tackling ASB now formed a core part of a social landlord's function as it contributed to the objective of building and sustaining stable communities:

You might think that [as a social housing provider] we should focus on building houses and repairs and collecting rents [rather than dealing with ASB], but we don't actually build houses any more, and I know it's a bit of a cliché, but we still have a responsibility for building communities. There is still a need out there to work with communities and deliver a service that makes that particular community more confident and stable.

(ASB Manager, 2011)

Under both Labour and the Coalition, social housing providers have been told that they 'shouldn't just be concerned with bricks and mortar, they must also be involved in building better, safer communities'. 55 Tackling ASB thus is 'no longer an optional extra' as one local manager phrased it. Successive New Labour governments enforced this message through extensive auditing of social housing providers' ASB policies and practices. ${ }^{56}$ Whilst the Coalition government has removed compulsory auditing, they have reaffirmed the expectation that tackling ASB is a service that social housing providers should provide. $^{57}$

Despite the fact that not all social housing providers have a specialist unit, practitioners worried that the 'essential' work of ASB management would remain undone in their localities if their unit were to be disbanded. They argued that they had developed an expertise in responding to problems of ASB that others had come to rely upon. If they were no longer in place, others would struggle to manage the complex work of utilizing the extensive toolkit of interventions including engaging in multi-agency partnerships:

You need to have a specialist team to deal with ASB complaints which is due to the complexities, it's due to being able to have that detailed knowledge of the tools and remedies ... [I]t's unavoidable having specialist teams. Whether we will all be able to operate to the size and capacity which we've had previously, I don't know, but that applies equally as well to different departments.

(ASB Manager, 2011)

55 H. Blears, 'Help for landlords to tackle anti-social behaviour' (2008), at: <http:// webarchive.nationalarchives.gov.uk/+/http://www.communities.gov.uk/news/ corporate/704905>.

56 Audit Commission, op. cit., n. 31.

57 Home Office, op. cit., n. 3. 
There was also concern that without specialist officers ASB management would become an organizational 'afterthought' as generic housing officers would not be able to dedicate sufficient time to this complex task:

When they were dealt with [by generic housing officers], with the best will in the world, ASB often fell off the table and the reason for that was they had to do other things. They had to do allocations, general breaches of tenancy, successions, assignments, whatever it was ...

(ASB Manager, 2011)

Furthermore, practitioners stated that as partner agencies such as the police, who had come to rely upon them, cut back on resources due to budget restraints and refocused on their core work ('real crime'), the need for social housing to act upon ASB would be more vital than ever. ${ }^{58}$

In defending the continuation of specialist ASB units, practitioners frequently referred to customer surveys, stating that results invariably found tackling ASB to be a high priority:

We've had to [accept] cut budgets, but with regards to the ASB service, we have to really do what our customers want and ASB is up there as a priority for our customers. The company knows that they have to buy into [it] because if they don't we will end up with estates where people don't want to live.

(ASB Manager, 2011)

In an opinion piece for the Guardian, Matt Jones, the Assistant Director of Communities and Neighbourhoods at City West Housing Trust, summarized these arguments as follows:

For landlords, the ASB agenda has not gone away. It remains a high priority for our tenants and will undermine the fabric of our communities and core business if we fail to tackle the problem ... Even in this age of austerity, it is paramount that resources to tackle ASB are protected from the inevitable cuts to frontline services ... If housing associations take their foot off the pedal and attempt to direct, admittedly scarce, resources elsewhere, our tenants would be the first to tell us what they thought about it. ${ }^{59}$

Nationwide studies have consistently shown that individuals living within social housing are more likely than those living in privately rented or owneroccupied accommodation to perceive ASB to be a serious problem in their locality. ${ }^{60}$ The previous New Labour governments and the Coalition government have recognized this, giving social housing providers a prominent role in tackling ASB and encouraging residents to expect their social landlord to act upon such behaviour. ${ }^{61}$

58 Her Majesty's Inspectorate of Constabulary, Policing in austerity: One year on (2012).

59 M. Jones, 'Tackling antisocial behaviour is still a priority' Guardian, 4 October 2012, at: <http://www.guardian.co.uk/housing-network/2012/oct/04/antisocialbehaviour-social-housing-budgets $>$

60 S. Mackenzie, J. Bannister, J. Flint, S. Parr, A. Millie, and J. Fleetwood, The drivers of perceptions of anti-social behaviour (2010).

61 Home Office, op. cit., n. 26; Home Office, op. cit., n. 3. 
Despite apparent self-assurance, a number of the ASB units were attempting to develop systems to help evidence their value in these times of budget cutbacks. This, however, is not something they found straightforward. The nebulous nature of ASB and the breadth of work they undertake (often in partnership with other agencies) mean there is a difficulty in identifying the appropriate measures of success. Practitioners mentioned a range of measures. This included the number and costs of interventions used; the number of perpetrators who following an intervention have amended their behaviour or at least not come into further contact with the authorities; the number of complainants satisfied with the outcome of a case; and annual surveys of residents' perceptions of ASB in their locality. Even relying on a combination of these measures does not provide an answer to the question of whether particular working practices provide value for money. ${ }^{62}$ The problem is compounded by a lack of national data which limits benchmarking. HouseMark, who provide an ASB benchmarking service, is attempting to improve this situation although its work on calculations of value for money is still in its infancy. ${ }^{63}$ Whilst units were confident of surviving the cuts, their problems with evidencing utility and cost effectiveness pose an on-going risk to them and the wider community safety industry.

\section{THE DEVELOPMENT OF A BROAD HABITUS}

At the core of the habitus found within units were three objectives that practitioners saw themselves delivering on behalf of their social landlord: the protection and support of victims and communities from ASB, behavioural transformation and, if necessary, the enforcement of good behaviour. These objectives, which are common to the wider community safety industry, ${ }^{64}$ are part of what Garland labelled 'the new criminologies of everyday life ... that are quite different from [or at least go beyond] the traditional goals of prosecution, punishment and "criminal justice". 65

The role of ASB units is in part to act as a new 'thin blue line' protecting victims and communities from the chaos of crime and disorder. ${ }^{66}$ For practitioners, ASB undermines a sense of community and the role of their unit is to assist communities in defending themselves against individuals who seek to undermine it:

62 HC Public Accounts Committee, Forty-fourth Report, Tackling Anti-Social Behaviour, HC (2006-2007) 246; National Audit Office, Tackling Anti-Social Behaviour, HC (2006-2007) 99; D. Prior, "The "Problem" of Anti-Social Behaviour and the Policy Knowledge Base: Analysing the Power/Knowledge Relationship' (2009) 29 Critical Social Policy 5.

63 HouseMark, op. cit., n. 15.

64 Hughes and Gilling, op. cit., n. 8; Hughes, op. cit., n. 8.

65 Garland, op. cit., n. 7, p. 17.

66 R. Reiner, Policing (1996); R. Reiner, The Politics of the Police (2006). 
They are damaging the community. They are ruining people's lives. If you like they are treating the community with contempt ... I think we have got to say to them we are not going to let you treat the community with contempt.

(ASB Officer, 2007)

The community is seen as a 'collective victim ${ }^{, 67}$ as vulnerable to crime and disorder as individuals. A practical example of this is the Community Harm Statement, which was developed by a local ASB unit and has now been adopted by the Coalition and promoted nationwide. ${ }^{68}$ This tool is designed 'to highlight the impact of harm on a community caused by ASB' in much the same way as a victim impact statement does for an individual. ${ }^{69}$

Practitioners recognized that if too great a focus is placed on the community as a collective victim, there is a risk that individual victim vulnerabilities will be missed. This issue was brought to national attention following the high-profile and tragic case of Fiona Pilkington, who took her own life and that of her severely disabled daughter in 2007 after suffering a sustained campaign of harassment and nuisance behaviour. ${ }^{70}$ Criticisms of the failings of local agencies to recognize the complainants' needs in this case have led to a greater focus within the ASB industry on victim vulnerability. ${ }^{71}$ Both in interviews and policy documents there was evidence that units had recently established or improved policies and procedures around victim protection. This includes training officers to provide victim support, establishing dedicated victim support officer roles in some larger teams, and the conducting of risk assessments to identify vulnerable victims. The construction of ASB regulation as offering necessary protection to helpless victims is one that has frequently been relied upon by politicians, who have emphasized that the focus of the ASB agenda must be the delivering of 'a quiet life ${ }^{72}$ so that everyone "has the right to feel safe in their home and in their neighbourhood' ${ }^{73}$

In responding to complaints of $\mathrm{ASB}$, practitioners saw their role as tackling the underlying causes of the problem. The typical habitus found within units encompassed a bounded rational-choice understanding of the behaviour of perpetrators, ${ }^{74}$ where it is recognized that individuals may not

67 Hughes, op. cit., n. 8.

68 Chartered Institute of Housing (CIH), Community Harm Statement: Guidance notes for social landlords (2012).

69 id., p. 2.

70 Independent Police Complaints Commission, IPCC report into the contact between Fiona Pilkington and Leicestershire Constabulary 2004-2007 (2009).

71 id.; CIH, How to Manage Anti-Social Behaviour Cases Effectively (2011); Home Office, op. cit., n. 3; J. Donoghue, 'Reflections on Risk, Anti-Social Behaviour and Vulnerable/Repeat Victims' (2013) Brit. J. of Criminology (first published online 14 May 2013, doi:10.1093/bjc/azt023).

72 Labour Party, op. cit., n. 42.

73 Home Office, op. cit., n. 39, p. 1.

74 D.B. Cornish and R.V. Clarke, The Reasoning Criminal: Rational Choice Perspectives on Offending (1986). 
be able to fully comprehend the implications and rationality of their behaviour due to pathological or social constraints; however, they maintain some freedom of choice in their actions and are held responsible. In line with government rhetoric, if a change in behaviour does not occur sufficiently quickly, if respite is not delivered, then the interests of victims or the community prevail and enforcement actions are considered: ${ }^{75}$

There's usually a reason why somebody behaves in an antisocial manner. They don't just wake up one day and think, 'I'm going to be a bloody nuisance to my neighbours today.' There is something going on and once you have established what that something is and you have some kind of a relationship with your subject then, more often than not, you can resolve it by other means. They might need medicating, they might need support, they might be inappropriately housed; they might need to go somewhere else ... However, sometimes you get them and they are bloody-minded and they do want to just cause a nuisance, but if that's the case ... I'd be saying to them, 'I'm sorry, [we] don't want you as a tenant. If you can't engage with me and you don't want this help and support and you're choosing to behave like this then go and do it somewhere else', and I'd terminate the tenancy.

(ASB Manager, 2011)

Guided by this rationale, ASB units engage in work which would be considered as combining aspects of policing, social work, housing, environmental health, prosecution, mediation, and probation. It is artificial to talk of strict delineations between these different occupations but practitioners were becoming increasingly willing, with or in some cases without cooperation, to cross occupational boundaries. ${ }^{76}$ Table 2 provides a breakdown of the different aspects of a typical unit's role and the interventions they may utilize based on the interviews and policy documents.

Practitioners borrow interventions from different fields of behavioural management without necessarily understanding fully their theoretical underpinnings and risks associated with them. The extent and quality of training does not rival that required of traditional disciplinary-based professions (such as the police or social services). Most of the practitioners came from a background in housing (see Table 1) and had no formal qualifications in ASB management. Training varied across the units and was heavily dependent on local budgets (which were shrinking) and the priorities of the units' manager. In the absence of extensive training, institutional history plays an even more prominent part in the development of habitus, with practitioners' mentalities shaped through (direct and shared) experience of the environments in which they operate. ${ }^{77}$

To engage adequately in such a diverse range of work requires a comprehensive knowledge and skill set. Arguably, it becomes difficult and

75 Cameron, op. cit., n. 41.

76 See the penultimate section of this article for discussion of the differing responses from other agencies to such expansionism.

77 D. Cooper, 'Against the Current: Social Pathways and the Pursuit of Enduring Change’ (2001) 9 Feminist Legal Studies 119. 


\begin{tabular}{ll}
\hline Role & Methods Used \\
\hline Investigation & $\begin{array}{l}\text { Surveillance } \\
\text { Interviews with perpetrators, victims, and witnesses } \\
\text { Information sharing with other agencies }\end{array}$ \\
& $\begin{array}{l}\text { Use of noise-monitoring equipment } \\
\text { Enforcement }\end{array}$ \\
& $\begin{array}{l}\text { Warnings } \\
\text { ASBOs/injunctions } \\
\text { Tenancy demotions }\end{array}$ \\
& Evictions \\
Bntervention & Behavioural agreements \\
& $\begin{array}{l}\text { Mediation } \\
\text { Referral for support, for example, drug or alcohol problems }\end{array}$ \\
& Family Intervention Projects \\
Victim Support & Keeping victims informed \\
& Providing counselling \\
Prevention & Educational programmes \\
& Diversionary schemes
\end{tabular}

inefficient for any one person to possess it all and therefore there has been a move towards specialization of roles within larger units. Such specialization often takes place as occupations develop and expand. ${ }^{78}$ Table 3 provides a breakdown of the personnel in the three largest units who participated in the 2011 interviews. This is contrasted with the personnel within those units in 2006. The six larger units from 2011 have witnessed an increasing diversity of specialist roles. Within several of the smaller teams where there was not the capacity to have specialist staff, case officers had taken the lead on a particular aspect of the unit's work (making them the ' $\mathrm{go}$ to' person in complex cases).

Specialization highlights an important aspect of the concept of habitus which acknowledges that not all members within a team will share an identical working culture. ${ }^{79}$ The unique aspects of a specialist officer's role mark them out from their generic officer colleagues. They have additional training, although the extent of this varies across the units, and engage with agencies and disciplines to a depth that generalist colleagues do not. The fields in which they operate are different. Specialist officers are particularly useful as expanders of mission, being more likely to push the boundaries of

78 G. Hunt and P. Wainwright (eds.), Expanding the Role of the Nurse: The Scope of Professional Practice (1994); B. Loveday, 'Contemporary challenges to police management in England and Wales: Developing strategies for effective service delivery' (1995) 5 Policing and Society 281.

79 Chan, op. cit., n. 10. 


\begin{tabular}{|c|c|c|}
\hline & 2011 & 2006 \\
\hline Unit A & $\begin{array}{l}2 \text { Managers } \\
7 \text { Case Officers } \\
3 \text { Victim Support Officers } \\
1 \text { Perpetrator Support Officer } \\
1 \text { Business Development Officer } \\
1 \text { Child Safety Officer }\end{array}$ & $\begin{array}{l}2 \text { Managers } \\
8 \text { Case Officers }\end{array}$ \\
\hline Unit B & $\begin{array}{l}1 \text { Manager } \\
12 \text { Case Officers } \\
1 \text { Mental Health Officer } \\
1 \text { Intervention Officer } \\
1 \text { Clerical Assistant }\end{array}$ & $\begin{array}{l}1 \text { Manager } \\
11 \text { Case Officers } \\
1 \text { Youth Officer } \\
1 \text { Clerical Assistant }\end{array}$ \\
\hline Unit C & $\begin{array}{l}3 \text { Managers } \\
12 \text { Case Officers (including hate } \\
\text { crime specialist) } \\
2 \text { Domestic Abuse Officers } \\
1 \text { Surveillance Officer } \\
2 \text { Clerical Officers }\end{array}$ & $\begin{array}{l}3 \text { Managers } \\
8 \text { Case Officers } \\
\text { (including hate crime } \\
\text { specialist) } \\
1 \text { Clerical Officer }\end{array}$ \\
\hline
\end{tabular}

their work in their particular area as they feel they are becoming more expert in it and have the time to develop better links with associated practitioners from other occupations.

As remits expand, power becomes more concentrated. As well as extensive powers of surveillance and investigation, ASB units can take action to have someone imprisoned, evicted or injuncted as well as the power to require (or at least place substantial pressure) on someone to engage with counsellors, therapists, and mediators. Units have an impressive ability to exert social control on their communities and, in particular, individuals and groups perceived by those communities to be behaving 'anti-socially'. The concentration of power is accompanied by a lack of adequate checks and balances. The organic development of the ASB occupation means that, as with other new entrants to the order maintenance field, there is a limited system of supervision and review. ${ }^{80}$ The lack of a national or regional hierarchy compounds this as power remains concentrated at the local unit level. The Coalition government's localism approach of regulating less and trusting more requires robust local systems of accountability, which have yet to take root.

80 Crawford, op. cit., n. 18. 


\section{THE INFLUENCE OF A CHANGING NATIONAL POLICY AGENDA ON THE HABITUS OF UNITS}

The national policy agenda on ASB promoted by New Labour has undoubtedly been an important influence on units. The steering mechanisms discussed in the background section of this article have been successful in encouraging the establishment of units and shaping the development of the habitus within them. One frequently mentioned mechanism in interviews and policy documents was the Respect Standard for Housing Management. ${ }^{81}$ This document contains a set of commitments on the management of ASB based on the Respect Agenda. The commitments include protecting communities through swift enforcement in combination with prevention and early intervention to tackle ASB ${ }^{82}$ Although the standard is voluntary, over 500 agencies have become signatories. ${ }^{83}$ Once they sign, they may refer to the standard and make use of its branding on their official documentation. ${ }^{84}$ Being able to advertise that they are meeting this national standard provides a source of legitimacy for units. ${ }^{85}$ The standard has been a useful tool in encouraging agencies to reform their policies and procedures in line with the national shift from the Together Campaign (which was heavily enforcement focused) to the Respect Agenda (which called for a combination of enforcement, prevention, and intervention):

We are attempting in as far as possible to shift from what used to be an enforcement focus to a more preventative focus. Because that's where the government is now saying they want us to be looking at it from.

(ASB Officer, 2007)

I think what we've seen is a paradigm shift [in approach]. This has been reinforced through central government, through the regulatory regime and certainly the Respect standard.

(ASB Manager, 2011)

The second quotation uses the phrase 'reinforced' which suggests a more symbiotic relationship between central government policy and local practice. In introducing reforms, both Labour and the Coalition have talked of responding to the needs of practitioners. ${ }^{86}$ The Social Landlords Crime and

81 Department for Communities and Local Government, The Respect Standard in Housing Management (2006). In 2012, as part of its localism agenda, the Coalition delegated responsibility for the standard to the Charted Institute of Housing who issued

82 id. a redrafted version in 2012. CIH, Respect-ASB Charter for Housing (2012).

$83 \mathrm{CIH}$, id., at $<$ http://www.cih.co.uk/respectcharter $>$.

$84 \mathrm{CIH}$, 'CIH charters frequently asked questions', at: <http://www.cih.co.uk/ resources/PDF/Policy\%20free\%20download\%20pdfs/Frequently\%20asked $\% 20$ questions.pdf>.

85 Although one should note that social landlords may self-certify their adherence to the standard.

86 Home Office, op. cit., n. 3. 
Nuisance Group and the Charted Institute for Housing regularly lobby national policymakers on behalf of local practitioners.

Given the close association of the ASB agenda with New Labour, there was some doubts among practitioners that the Coalition would remain as 'committed to the cause' (ASB Manager, 2011). The current government's localism agenda initially suggested to practitioners that they 'would be left to their own devices' (ASB Manager, 2011). However, the 2011 interviews took place in the aftermath of the English riots and following the government consultation document promoting a new package of interventions on ASB. ${ }^{87}$ This appears to have provided reassurance to practitioners that central government continues to view the role of social landlords in tackling ASB as important. ${ }^{88}$ If the Coalition had not quickly adopted a pro-active role in this policy field, ASB practitioners would for the first time have operated without a strong central government guiding hand, which may have had implications for the future development of their habitus.

Despite attention from central government providing practitioners with a level of reassurance, units were willing to adapt and in some cases reject national-level excesses of penal populism or punitive display. ${ }^{89}$ One example has been the ASBO, which New Labour governments struggled to persuade practitioners to use despite heavy promotion. ${ }^{90}$ In the 2011 cohort, interviewees voiced scepticism towards the Coalition government's proposed policy of removing, in serious cases, the requirement for a social landlord to establish, in proceedings for possession, that the ASB occurred within the locality of the dwelling house. ${ }^{91}$ The government announced the proposal in the light of the riots of summer 2011 (it was during this period that the interviews were conducted). The government's argument is that if someone engages in such disruptive or violent behaviour they forfeit their right to housing provided by the state, but practitioners saw problems in pursuing such a policy. There were concerns that such a change would effectively make them moral guardians of their residents rather than simply of their localities, transforming their remit beyond which they were currently comfortable. Practitioners worried that they would face pressure to take action against their tenants no matter where the behaviour in question took place and even if such behaviour had no impact on their housing situation. The fact that the majority of the practitioners had a habitus developed in housing appeared to heighten their attachment to the concept of locality. ${ }^{92}$

87 Home Office, op. cit., n. 39.

88 G. Shapps, 'Letter from Rt Hon Grant Shapps MP - extending social landlords' powers to seek possession for criminality and anti-social behaviour' (2011) at: $<$ http://www.communities.gov.uk/publications/housing/antisocialbehaviourconsult $>$; Home Office, op. cit., n. 3.

89 Garland, op. cit., n. 7.

90 Burney, op. cit., n. 5.

91 Shapps, op. cit., n. 88.

92 See Table 1. 
Some interviewees also expressed concern that the Coalition's policy would lead to the over-policing and over-punishment of those living in social housing suggesting a social democratic influence to their habitus:

It's shocking that tenants of social housing are seen to be the scum of the earth. They're not. You know the riots that were held a couple of months ago were student riots from middle class families. Were they threatened with having their home to be taken off them? No. So it's social control, so I'm very opposed ... So don't demonise our youths and don't demonise social housing tenants.

(ASB Manager, 2011)

Whilst national policies and initiatives clearly influence the fields in which practitioners operate and ultimately, at times, the development of the habitus within units, to portray them as pawns or dupes of central government would be to misrepresent their work. It would also fail to take account of other influences on units including community expectations and inter-agency relationships.

\section{THE INFLUENCE OF COMMUNITY EXPECTATIONS ON THE HABITUS OF UNITS}

A problem that ASB units face is that while it is easy to say that their role is to defend communities from 'ASB', it is more difficult to answer the question of what exactly they mean by the use of this term and thus what it is they are defending against. The label of 'ASB' can encompass a wide spectrum of annoying or harassing behaviour, ranging from minor nuisance to serious criminality. The Crime and Disorder Act 1998, s. 1 defines ASB as behaviour likely 'to cause harassment, alarm or distress'. An alternative definition is provided in the Housing Act 1996, s. 153A(1)(a) which covers individuals 'engaging in or threatening to engage in conduct causing or likely to cause a nuisance or annoyance' to another resident, occupant or person involved in lawful activity on behalf of the social landlord. These definitions are 'ill-defined and open to a very shifting agenda'. ${ }^{93}$ The imprecision of the definition of ASB invites a subjective and diverse range of interpretations from practitioners, government, and communities, which can differ depending on time and locality. ${ }^{94}$

93 C. Hunter, 'Looking two ways at once: anti-social behaviour, law and social inclusion' (2003) 8, at <http://www.york.ac.uk/chp/hsa/papers/autumn03/Hunter.pdf>.

94 R. Atkinson, 'Housing and the New Spaces of Disciplinary Control: The Compounded Citizenship of Social Renting' in Housing, Urban Governance and AntiSocial Behaviour: Perspectives, Policy and Practice, ed. J. Flint (2006) 99-116; Crawford, op. cit., n. 6; J. Flint, 'Surveillance and Exclusion Practices in the Governance of Access to Shopping Centres on Periphery Estates in the UK' (2006) 4 Surveillance \& Society 52. 
Central governments have encouraged practitioners to adopt a responsive approach in defining ASB. A New Labour government minister in 2006 was reported to have stated that ' $[\mathrm{ASB}]$ is whatever the victim says it is'. ${ }^{95}$ The Coalition government proposes the introduction of a 'community trigger' that would require practitioners to take action when a certain number of complaints have been received. ${ }^{96}$ The White Paper states that:

Individuals and communities themselves know exactly what problems they face, and so can often be the most effective actors in establishing what is and isn't acceptable in their neighbourhood ... ${ }^{97}$

In adopting such an approach there is a risk that those with the loudest voices may establish what is normal or acceptable behaviour in their community, while those with no voice will find their behaviour classified as anti-social. The views of adults may be favoured over children, ${ }^{98}$ whilst those who are different, such as those with mental health difficulties may be targeted for not being "normal'. ${ }^{99}$ Practitioners frequently referred to the difficult role they had in balancing the demands of complainants with the rights and needs of those who were the subject of the complaints. All of the units had actively to manage perceptions and expectations:

A lot of it is about perceptions ... I think you'll find with a lot of people, the minute they see a group of kids, they could be doing nothing, they could be sitting on the ground doing their homework, but because there may be a dozen of them, the perceptions are 'oh they'll be drinking, they'll be taking drugs.' And a lot of our work is about reducing those perceptions.

(ASB Manager, 2011)

A common concern among practitioners was that they were being drawn into an ever-greater range of minor disputes:

People are fearful [of repercussions] ... so they ${ }^{\circ} \mathrm{d}$ much rather ring the council and send the council round to tell off the person across the street, which then causes another set of tensions, because if somebody official knocks on your door and says your kids are causing a problem, it's much worse than if your neighbour does.

(ASB Manager, 2007)

The majority of practitioners were conscious of this dilemma in their working practice and some units had put in place neighbourhood mediation schemes and forums to encourage self-regulation within communities. ${ }^{100}$

95 D. Hewitt, 'Bovvered? A legal perspective on the ASBO' (2007) 14 J. of Forensic and Legal Medicine 355, at 359.

96 Home Office, op. cit., n. 3.

97 id., p. 18.

98 Squires and Stephen, op. cit., n. 37.

99 N. Cobb, 'Patronising the Mentally Disordered? Social Landlords and the Control of “Anti-Social Behaviour” Under the Disability Discrimination Act 1995' (2006) 26 Legal Studies 238.

100 A.P. Brown, A. Barclay, R. Simmons, and S. Eley, The Role of Mediation in Tackling Neighbour Disputes and Anti-Social Behaviour (2003). 
There were concerns among some that pressures were increasing because of the current fiscal climate, which was causing partner agencies to reduce or withdraw services, for example, a number of units reported the loss of their local mediation service. Practitioners were having to learn to take a more forthright approach in establishing limits to their roles as in the quotation below:

I think initially, we were very much wading through treacle. You weren't sure how to deal with things, or maybe we gave more credence to a complaint than we should have done. Whereas now, we're very clear. A neighbour dispute is not necessarily ASB ... We're very clear about where the rules lie. That means that we can deal with the lesser issues very quickly, which frees up our time to deal with the more serious issues.

(ASB Manager, 2011)

Despite expectation management, a responsive approach means that units are dependent at least to an extent on the types of complaints they receive, which is in turn dependent on the types of population and spaces which they govern. ${ }^{101}$ In interviews, units that are responsible for significant amounts of communal space were more likely to report problems with congregating youths, whilst those who worked for organizations with a sizeable stock of poorly constructed flats were particularly concerned with reports of noise nuisance. Likewise, units that had responsibility for housing estates that are disparate in terms of age profile found that inter-generational lifestyle conflicts were a source of complaints, whilst units whose areas covered ethnically diverse communities were more likely to raise the problem of hate crime. Some units reported particular problems with drug abuse whilst others reported alcohol to be a major factor behind complaints. There was evidence of teams tailoring their skills to their workload. Those who had particular problems with noise nuisance, for example, had purchased their own noise monitoring equipment and trained staff to use it. A unit with responsibility for a sizeable number of ethnically diverse neighbourhoods had recruited a hate crime officer. Thus, the experience, skills, and knowledge base within teams varies in response to their communities, ensuring that there is not an identical habitus across the units.

Most units had in place a system for categorizing complaints of ASB, which allowed them to quickly prioritize and tailor their response. This included the use of risk assessments on the vulnerability of complainants. ${ }^{102}$ A majority of the units utilized electronic databases for the recording of cases suggesting a move towards a more technical approach. ${ }^{103}$ Recording and categorization allows units to gather statistics and in turn evaluate and

101 Atkinson, op. cit., n. 94.

102 Donoghue, op. cit., n. 71.

103 E. Friedson, Professional Powers: A Study of the Institutionalization of Formal Knowledge (1988). 
improve practice. ${ }^{104}$ This allows practitioners to claim that they are increasingly basing their work upon verifiable expert knowledge rather than common sense, thus increasing their professional legitimacy. ${ }^{105}$ However, categorization sits uneasily with the flexible, responsive approach that teams pride themselves on. Due to the wideness of scope and compounded nature of ASB, fitting complaints into discrete categories is not straightforward and other agencies including the police have struggled in this task. ${ }^{106}$ Furthermore, there is currently no consensus among ASB practitioners as to which case management package to use. A recent survey of 150 agencies found over 20 different software packages in use with in-house IT solutions the most common. ${ }^{107}$ The lack of compatibility between packages inhibits information sharing (an issue, which will be returned to in the following section) and benchmarking across the sector.

\section{THE INFLUENCE OF PARTNERSHIP WORKING ON THE HABITUS WITHIN UNITS}

The approach has changed because of multi-agency working.

(ASB Officer, 2011)

From the interviews and policy documents, it was clear that multi-agency cooperation was an integral part of the work of ASB units and a significant influence on their habitus. Practitioners discussed a range of agencies with whom they worked including the police, social services, education and youth services, mediation facilitators, and Victim Support. One forum for cooperation is the Crime and Disorder Reduction partnerships or Community Safety Partnerships, which are mandated by statute. ${ }^{108}$ However, ASB practitioners also reported membership of various local partnerships dealing with specific issues such as domestic violence or youth crime. The leadership structure within these partnerships differs across localities. In some partnerships there is a designated team or officer who co-ordinates; in other localities it is simply a regular meeting of practitioners from different agencies. Where a locality has a specialist ASB unit, partner agencies can treat it as an important resource. Other agencies struggle to match the versatility of the toolkit available to ASB units and at least until recently they have been a growth industry eager to expand their work. An example was

104 A criticism of the practice of ASB units has been the lack of such evaluations. See, for example, HC PAC, op. cit., n. 62.

105 Brown, op. cit., n. 33; Friedson, op. cit., n. 103.

106 Home Office, Focus on the victim: Summary Report on the ASB Call Handling Trials (2012).

107 HouseMark, op. cit., n. 15.

108 Crime and Disorder Act 1998, ss. 5-7. 
domestic violence, which nearly all interviewees in the 2011 cohort saw as falling within their remit:

Domestic violence was our second most investigated category of ASB [last year]. Now you wouldn't have seen that five years ago, because it would have been referred to another agency or it would have been felt it's criminal or it's not related to the housing management function. [But] it is because they are our customers and [where they] experience behaviour or fear within their property ... there's certainly a role [for us] to play.

(ASB Manager, 2011)

Practitioners referred to how the establishment of local Multi-Agency Risk Assessment Committees (MARACs), aided by funding from central government, had encouraged different agencies to cooperate on the issue of domestic violence. ${ }^{109}$ The participation of ASB units in this framework had encouraged them to see domestic violence as something they should be tackling. This had, in turn, encouraged other agencies to see the potential role that ASB units could offer in assisting with the problem. According to interviewees from the 2011 cohort, this included the fact that much domestic violence takes place within the home and thus firmly within their space of governance. ASB practitioners argued that their relative ease of access to their tenants' homes put them in an excellent position to play a proactive role in identifying and investigating cases. In addition, the interventions at their disposal allowed them to offer a uniquely holistic response combining enforcement and support. This included assisting with support and/or rehousing of the victim if necessary, whilst taking eviction proceedings and injunctive action against the perpetrator to exclude him from the area. This action was taken with the cooperation of other agencies, with ASB units increasingly taking a higher profile role as their experience with such cases grew. A number of the 2011 units had established the role of dedicated domestic violence officers, which further encouraged other agencies to see the ASB unit as a lead agency on the issue. There was a notable selfconfidence in embracing this new aspect to their role. This response to domestic violence provides an example of how multi-agency working can result in partner agencies redefining their relationship within one another and, in turn, redefining their own perception of what it is they do. ${ }^{110}$

The most commonly mentioned agency in interviews was the police, with whom generally positive working relationships where reported. Practitioners

109 N. Steel, L. Blakeborough, and S. Nicholas, Supporting high-risk victims of domestic violence: a review of Multi-Agency Risk Assessment Conferences (MARACs) (2011); Donoghue, op. cit., n. 71.

110 This phenomenon has been witnessed in other areas of multi-agency working, see R.C. Mawby and A. Worrall, "“They were very threatening about do-gooding bastards": Probation's changing relationships with the police and prison services in England and Wales' (2011) 3 European J. of Probation 78; B. Reid, 'Partnership and Change in Social Housing' in Partnership Working: Policy and Practice, eds. S. Ballach and M. Taylor (2001) 77-96. 
share with the police the criminal policy aspects of their role, including a mission to protect victims and maintain social order in their communities. ${ }^{111}$ Practitioners frequently spoke of how they acted as an important back-up to the police in dealing with behaviour which the police would struggle to commit significant resources to given their need to focus on 'serious crime':

If you go back even ten years or certainly twenty years ... the traditional view was that we let the police deal with all of these issues, whatever they were, crime, disorder, ASB, traffic offences, the police dealt with absolutely everything. I think we have moved on from that now ... I think it is no longer practical to leave it all to the police. I think the police themselves want help and want assistance. They are looking for organisations like ... [us] to assist them.

(ASB Manager, 2007)

Practitioners, then, were at times an alternative provider of policing in their communities, at least as regards less serious criminality. From receiving complaints, to gathering evidence, to interviewing suspected perpetrators, to issuing warnings, their role shared much in common with that of the police. In some respects, the ASB practitioners' role went further in that, unlike the police, they also made the decision as to whether to pursue legal action against a perpetrator, a role that the police have lost to the Crown Prosecution Service. The logic behind this curtailment of police power applies arguably to ASB practitioners today, which is that it is best to avoid having the same officers investigate and prosecute cases to ensure independent review of a decision to go to court. ${ }^{12}$

One practical measure, which four of the 2007 units had taken to improve relations between themselves and the police, was to second police officers to their units. In the following quotation the manager explains the value of having a seconded police officer on their team:

We've got police officers in our team which I think is invaluable because on a day-to-day basis once we get the systems up and running we'll have access to the police information that we need.

(ASB Manager, 2007)

Seconded police officers appeared to play an important role in allowing the translation of information from one discourse and method of governance to another. ${ }^{113}$ With no seconded police officers in the 2011 units, one might have expected information sharing to be problematic: however, it appears that as ASB units have become more established they have developed closer relations with the police (including information sharing protocols), which means that formal secondments are no longer necessary. The extent of information sharing varied across the units depending on relations with their

111 Reiner, op. cit., n. 66.

112 M. McConville et al., The Case for the Prosecution: Police Suspects and the Construction of Criminality (1991).

113 R.V. Ericson and K.D. Haggerty, Policing the Risk Society (1997). 
local police force. The closest relationship was reported by a unit in a large urban area who had recently starting receiving daily emails from the police providing information on those in the area who had been arrested or charged:

We've started to get overnight reports now ... so we can see who's been arrested for whatever ... If it's one of our [residents] we'll think 'okay what have they done?'... For example if it is shoplifting, we might write to them, but is that worthwhile evicting someone for? Probably not.

(ASB Manager, 2011)

This process communicates to the tenant that they are subject to a compounded system of governance and surveillance. ${ }^{114}$ It also allows the police to communicate to the ASB unit their trust and respect for their partners, encouraging them to 'buy in' to the policing agenda.

The other agency that practitioners frequently referred to was social services. Unlike with the police, relations between the two occupations have not been close:

One, they have never heard of partnership working; two, everyone has resource problems, everyone is stretched, but we are seeing things, we refer things to [social services] which you don't do all the time, but they are not interested.

(ASB Manager, 2007)

Garrett has argued there is an incompatibility between the ASB agenda, which attempts to criminalize social policy, and the habitus of social work. ${ }^{115}$ At a national level, the professional bodies representing social work have been openly critical of the measures pursued in the name of tackling the problem of $\mathrm{ASB}^{116}$ and central government has been equally critical at the perceived resistance of the profession. ${ }^{117}$ Social workers sit within the social policy realm whilst ASB practitioners sit both within the social and criminal policy realms. The respective occupations have different priorities, with social workers concerned principally with the welfare of their clients and defending the clients' interests. ${ }^{118}$ For ASB units, perpetrators may also be tenants but this does not place on them the same duty of care placed on social workers. ASB practitioners when deciding how to respond in a case will often take a pragmatic approach balancing the rights and welfare of the instigator of

114 Atkinson, op. cit., n. 94.

115 P.M. Garrett, "Making "Anti-Social Behaviour": A Fragment on the Evolution of “ASBO Politics” in Britain' (2007) 37 Brit. J. of Social Work 839; P.M. Garrett, " "Sinbin" Solutions: The "Pioneer" Projects for "Problem Families" and the Forgetfulness of Social Policy Research' (2007) 27 Critical Social Policy 203.

116 E. Ashenhurst-McGrattan, 'Response to the Proposed Draft Anti-Social Behaviour (NI) Order 2000' at <http://www.basw.co.uk/Default.aspx?tabid=54\&articleID=197>.

117 C. Jerrom, 'Social Workers Should Not Make Excuses for Clients' Behaviour, Says Minister' at <http://www.communitycare.co.uk/Articles/2003/03/17/40032/socialworkers-should-not-make-excuses-for-clients-behaviour-says.html>; L. Ward, 'Asbo Chief Rounds on Liberal Critics' Guardian, 10 June 2005, 9.

118 British Association of Social Workers, The Code of Ethics For Social Work (2012). 
the ASB against those of the victim or the wider community. ASB practitioners' lack of professional accreditation and formal qualifications may make social workers sceptical of their capacity to engage competently in interventionist work. Such scepticism has been in evidence in relations between others occupations such as probation and the prison service. ${ }^{119}$

Despite such difficulties, the two occupations increasingly work together and there is evidence that this is improving relations:

It's got a little bit better more recently ... for instance, if there is an issue in a family and there is young children there or whatever, we have to do a referral to social services to say this is what's happening. I find that now, they do tend to get back to you. Whereas before, you just never got nothing at all. We didn't even know if they had visited or if they hadn't or if they were working with that family or not.

(ASB Manager, 2011)

ASB practitioners in 2011 reported regular meetings with social work at various multi-agency panels dealing with domestic violence, racial hatred, and youth offending. A number of units had also worked with social services on family intervention projects, where perceived difficult families receive a holistic and multi-agency response to their behaviour. ${ }^{120}$ One unit had a parttime seconded mental health worker, who saw an aspect of the role as improving communications between mental health support, social services, and the ASB team:

We all do it, we all start playing games and getting ... positional, don't we? When we can start relating to one another, either within organisations or between organisations, then change occurs. I mean all different professions still have their own priorities ... But it's about getting them communicating to one another [whilst] still giving credibility to everybody's professional [perspective].

(Seconded Mental Health Officer, 2011)

Other members of the same unit reported that the presence of the mental health worker made a positive difference to inter-agency relations and made them more aware of possible mental health issues that could be affecting victims and perpetrators. Generally, though, reported relationships between teams and social (and related) services remained far from perfect and were certainly not as close as with the police. The overriding viewpoint from the ASB practitioners was that this meant that tackling the underlying causes of disruptive behaviour was made more difficult. Given the reported value of seconded officers, a possible method of improving relations would be to trial the secondment of social workers, at least on a part-time basis, to ASB units. Whilst such a proposal raises ethical issues for social work, it has the potential to give social work a greater influence on the habitus of ASB units.

119 Mawby and Worrall, op. cit., n. 110.

120 S. Parr, and J. Nixon, 'Rationalising Family Intervention Projects' in ASBO Nation: The Criminalisation of Nuisance, ed. P. Squires (2008) 161-78. 


\section{CONCLUSIONS}

ASB practitioners lack important aspects of professional power such as a professional association, accreditation, and a formal period of education or training. ${ }^{121}$ However, there was an identifiable shared, if not identical, habitus within the ASB units that participated in the research. The interviews and associated policy documents provide evidence of a common language, knowledge, ways of conceiving, and techniques for acting upon others. ${ }^{122}$ Practitioners enthusiastically espoused multi-agency working, demonstrating a willingness to pool resources to provide a solution to complex cases. Adopting a 'what works' approach, there was a willingness to learn and incorporate the best practice of others. Some of the participating units were innovators, willing to set aside traditional ways of doing things and develop new responses to the problems they faced. This included the establishment of specialist officers who were building expertise in their fields. The work of units in combating domestic violence was an important example of this. Practitioners also demonstrated a willingness to adapt to changes in external pressures upon them, such as reductions in funding or changes in government policy. They tended to embrace change confidently rather than engage in existential self-doubt, a phenomenon which has been documented in other occupations that have experienced significant change, such as social services and probation. ${ }^{123}$

The fields in which they operate have influenced the habitus within ASB units. Practitioners are constantly adopting, adapting to, and resisting the expectations upon them from government, their communities, and partner agencies. Due to the lack of a shared embedding within an educational or ethical framework, units are more at risk of succumbing to external pressures to alter their working practices without sufficient thought as to whether such practices are right in any occupationally normative sense. This is heightened by the fact that they float between traditional criminal and social policy fields of practice. In such situations, a lack of self-doubt risks discouraging sufficient self-reflection. Based on a New Labour government initiative, ${ }^{124}$ the Chartered Institute of Housing has published what equates to a voluntary national Code of Practice for ASB practitioners in social housing. ${ }^{125}$ This could be taken further by drawing up a code of ethics to encourage debate among ASB practitioners and the wider community safety field as to what, if

121 K.M. Macdonald, The Sociology of the Professions (1995).

122 P. Miller and N. Rose, Governing the Present (2008); N. Rose, Powers of Freedom: Reframing Political Thought (1999).

123 P.J. Baylis, 'Social Work's Protracted Identity Crisis' (2004) 11 Psychoanalytic Social Work, 55; Mawby and Worrall, op. cit., n. 110.

124 Department for Communities and Local Government, op. cit., n. 81.

125 CIH, op. cit., n. 81. 
any, shared ethical principles should underlie their daily decisions. ${ }^{126}$ The existence of such a code would not guarantee adherence. However, its production would engender a debate about what ASB units are for and would act as a source to which not only practitioners, but also other agencies, victims, and perpetrators could rely. ${ }^{127}$

For politicians of both the centre left and centre right, the appeal of governance through ASB is that it involves a pragmatic multi-agency approach to behavioural management within a populist discourse of zero tolerance of incivilities and criminal behaviour. For social housing providers, establishing and maintaining an ASB unit provides a method for demonstrating to their communities, partner agencies, and government that they are significant players in the populist behavioural management field. ASB units provide an embodiment of Simon's governance through crime thesis, where legitimacy and support (including financial assistance) is more readily maintained by those offering solutions to crime and disorder than those offering solutions to problems couched within a welfarist discourse. ${ }^{128}$ This may help to shield units from the worst of the cuts. It is likely, however, that in these austere times teams will need to rely on their versatility and creativity to ensure their survival. If these units do survive, the behaviour they will be dealing with and how they will be doing so is likely to continue to adapt and will serve as a good barometer of the direction of the national discourse on crime, disorder, and community well-being.

126 D. Dixon, 'The Normative Structure of Policing' in A Culture of Corruption: Changing an Australian Police Service, ed. D. Dixon (1999) 69-97; J.H. Kultgen, Ethics and Professionalism (1988).

127 D. Dixon, 'Legal Regulation and Policing Practice' (1992) 1 Social and Legal Studies 515; L. Meskell and P. Pels, 'Introduction: Embedding Ethics' in Embedding Ethics, eds. L. Meskell and P. Pels (2005) 1-28.

128 J. Simon, Governing Through Crime: How the War on Crime Transformed American Democracy and Created a Culture of Fear (2007). 